\title{
“LANTPYCATION" : METODE BARU BUDIDAYA MELON (Cucumis melo L.) RAMAH LINGKUNGAN
}

\author{
Budi Setiadi Daryono ${ }^{1)}$, Wiko Arif Wibowo ${ }^{1)}$,Hanifa Hanini ${ }^{1)}$,Muhammad \\ Rifqi $^{1)}$, Desy Retnosari ${ }^{1)}$, Hervin Indra Cahyana ${ }^{1)}$ \\ ${ }^{1}$ Fakultas Biologi Universitas Gadjah Mada, J1. Teknika Selatan, Sekip Utara, \\ Yogyakarta, 55281 \\ Email: bs_daryono@mail.ugm.ac.id
}

\begin{abstract}
Jamusan village is one of the areas that becomes the center of melon production at Prambanan subdistrict, Sleman, Yogyakarta. However, at this moment, the villagers of Jamusan still encountered many obstacles in melon farming. This is caused by the poor quality of the melon, crops that have not been handled well and the lack of farmer's knowledge about the management after harvesting, melon production that is not absorbed by the market. LANTPYCATION Program (Plant, Apply, and Diversification) aims to provide knowledge about quality and good management of the melons in the form of processed product diversification melon. The method applied in the implementation of this program which begins with socialization, counseling, training in management and cultivation of melons, good governance, advocacy and marketing of melon processed product. The result of the implementation of this method showed the increase of farmer's knowledge about good quality melon, farm management and procedures for the proper cultivation of melons in creating diversificated processed melon to improve the welfare of villagers Jamusan.It could be revealed that LANTPYCATION Program is a new method on sustainable agriculture of melon cultivation in Indonesia.

Keywords:Melon, Melon cultivation, Diversification processed melon.
\end{abstract}

Melon (Cucumis melo L.) merupakan salah satu buah tropika dari famili Cucurbitaceae yang memiliki potensi besar untuk dikembangkan sebagai produk buah unggulan melalui pemuliaan tanaman (Maryanto \& Daryono, 2011). Melonjuga merupakan buah yang banyak digemari masyarakat, selain karena kandungan gizi yang tinggi, melon mengandung $90 \%$ air dan $10 \%$ karbohidrat yang menyegarkan pada saat dikonsumsi (Samadi, 2007) serta kaya vitamin $\mathrm{A}, \mathrm{C}, \mathrm{D}, \mathrm{K}, \beta$-caroten, dan mineral (potassium, magnesium, phosporus, sodium, selenium, dan kalsium) (Ivanova, 2012). Konsumsi melon di Indonesia mencapai 1,34$1,50 \mathrm{~kg} / \mathrm{kapita} / \mathrm{tahun}$ (Direktorat Jenderal Holtikultura, 2004) serta produksinya mengalami kenaikan dari tahun 2010 sebanyak 85.161 ton menjadi 125.474 ton pada tahun 2012(Badan Pusat Statistik Nasional, 2014).

Salah satu wilayah yang memiliki potensi besar di bidang pertanian melon adalah Kecamatan Prambanan, Kabupaten Sleman, Yogyakarta. Luas wilayah Kec. 
Prambanan mencakup $35,4 \quad \mathrm{~km}^{2}$ dengan 6 desa/kelurahan. Kecamatan ini memiliki peran yang potensial sebagai sentra budidaya melon dan daerah yang memiliki luas panen, angka produksi, dan rata-rata produksi melon tertinggi di Kabupaten Sleman (Badan Pusat Statistik Sleman, 2014). Berdasarkan data statistik Desa Bokoharjo, dari 5.345 jiwa penduduk, $52,44 \%$ berupa lulusan SD (Sekolah Dasar) dan tidak tamat pendidikan dan $30,3 \%$ berprofesi sebagai ibu rumah tangga dan petani 42,8\% (Data Monografi Desa Bokoharjo, 2013).

Saat ini pertanian dan budidaya melon Indonesia belum berkembang dengan baik, termasuk Pedukuhan Jamusan, Kecamatan Prambanankarena seringkali mengalami infeksi jamur tepung misalnya pada tahun 2007 sehingga menyebabkan gagal panen(Maryanto \& Daryono, 2011). Menurut Sobir \& Siregar (2010)melon memiliki daya resistensi yang rendah terhadap infeksi Kyuri green mottle mosaic virus (KGMMV) serta jamur tepung (Powdery mildew). Ketahanan buah melon pasca panen terbatas akibat adanya pematangan secara enzimatis (Doyle et al.,2001), sehingga buah melon hasil panen yang tidak langsung dijual akan menjadi busuk dan terbuang. Melodi Gama-3 (MG3) merupakan kultivar melon hasil riset Laboratoriun Genetika dan Pemuliaan Fakultas Biologi UGM yang memiliki keunggulan berupaadaptasi terhadap cuaca ekstrim, respon toleran terhadap infeksi jamur tepung dan KGMMV serta masa panen yang lebih cepat (Daryono dkk,2012).
Menurut Daryono dkk (2014) budidaya melon ramah lingkungan yaitu teknik yang diaplikasikan untuk meminimalisir perusakan lingkungan karena budidaya melon yang meliputi teknik pembenihan, teknik seleksi buah, dan teknik penggunaan potensi lokal. LANTPYCATION(Plant, Apply, and Diversivication) merupakan metode terbaru budidaya melon ramah lingkungan berupa penerapan penelitian dengan basis pengabdian masyarakat. Tujuan dari program ini adalah untukmengaplikasikan hasil penelitian kultivar melon unggul dengan teknik budidaya yang ramah lingkungan, menambah nilai ekonomi dari hasil panen melon serta meningkatkan pengetahuan masyarakat Pedukuhan Jamusan, Desa Bokoharjo, Kec. Prambanan, Sleman D.I.Yogyakarta. Luaran yang diharapkan adalah kemandirian petani dalam budidaya melon unggul dengan mengedepankan aspek ramah lingkungan dan peningkatan ekonomi untuk kesejahteraan petani.

\section{METODE}

Program ini dilaksanakan selama 5 bulan, dari awal bulan Maret 2015 hingga akhir bulan Juli 2015. Metode yang digunakan berupa metode budidaya melon ramah lingkungan (Daryono dkk, 2014) yang dibagi menjadi 3 tahap, yaitu:

1. Penyuluhan

Penyuluhan dilakukan dengan sosialisasi kultivar MG-3 yang merupakan hasil penelitian yang telah dicapai Laboratorium Genetika Fakultas Biologi UGM dengan seluruh keunggulannya dan tata cara budidayanya. Setelah itu dilakukan sharing informasi dan diskusi dengan Kelompok Tani Jamusan terkait 
manajemen pertanian dan budidaya tanaman melon pra dan pasca produksi.

\section{Pelatihan (LANTPYCATION)}

Pelatihan metode barubudidaya melon ramah lingkungan, LANTPYCATION (Plant, Apply, and Diversification) merupakan pelatihan penanaman, pengaplikasian, dan pendiversifikasian pangan. Teknik budidaya melon dilakukan sesuai dengan tahapan budidaya melon (Daryono dkk, 2014). Petani dilatih mengenai tahap-tahap budidaya melon, aplikasi mulsa, dan teknik seleksi buah serta teknik penggunaan pupuk dasar (ZA, $\mathrm{KCl}, \mathrm{TS}$ ) dan pupuk kocor (NPK Mutiara 16-1616), insectisida (Metindo, Procleim, Marshal) dan fungisida (Amistartop, Manzate, Dithane) secara efisien yaitu penggunaan di fase vegetatif secara optimal dan di fase generatif secara minimal. Selanjutnya dilakukan teknik kastrasi dan polinasi untuk pelatihan produksi benih persilangan (Munshi \& Alvarez, 2008).Kemudian juga dilakukan pelatihan pengolahan hasil panen melon yang tidak terserap pasar dan memiliki nilai jual rendah apabila langsung dipasarkan tanpa pengolahan, menjadi produk yang bernilai jual tinggi berupakue, ice cream dan puding melon.

Modifikasi sederhana metode tersebut diharapkan petani memiliki kemandirian dalam mengaplikasikan kultivar melon unggul MG-3 yang ramah lingkungan dan peningkatan nilai ekonomi hasil panen melon melalui pengolahan pangan berbasis melon. Pelatihan budidaya melon secara efektif dan efisien diberikan kepada kelompok tani yang terdiri atas 23 orang dalam workshop. Pelatihan pengolahan olahan melon dilakukan terhadap kelompok PKK yang terdiri atas 20 orang ibu rumah tangga Pedukuhan Jamusan, Desa Bokoharjo.

3. Pendampingan berkala Pendampingan berkala dilakukan dengan tahapan berupa pembekalan, monitoring, dan diskusi kepada perwakilan kelompok tani. Hal ini dimaksudkan agar terjadinya transfer ilmu antar petani demi terwujudnya kemandirian setelah kegiatan ini berakhir, pendampingan lapangan secara langsung diberikan kepada 3 orang petani. Disamping itu, juga dilakukan pendampingan dalam hal pembentukan struktur organisasi kelompok yang terdiri dari Kelompok Tani Melon dan Kelompok PKK. Adanya pembentukan struktur ini bertujuan untuk mewujudkan program yang berkelanjutan.Pendampingan juga dilakukan dalam pemasaran produk kegiatan yang telah berhasil diproduksi.

4. Analisis Ekonomi

Analisis ekonomi dilakukan dengan membandingkan analisis ekonomi budidaya melon ramah lingkungan (Daryono dkk, 2014) dengan pengembangan terbaru menggunakan LANTPYCATION. Analisis ekonomi berperan dalam peningkatan ekonomi dan kesejahteraan masyarakat petani melon dan menjadi faktor pertimbangan dalam manajemen resiko budidaya melon

\section{HASIL DAN PEMBAHASAN}

1. Sosialisasi dan Penyuluhan

Dilaksanakan sebanyak dua kali secara formal dan informal antara pelaksana program dan kelompok tani Pedukuhan Jamusan (Gambar 1A). 
Dalam penyuluhan (Gambar 1B dan 1C) diberikan pematerian terkait budidaya melon dan aplikasi kultivar melon MG-3 serta perbincangan mengenai kondisi perekonomian, pertanian, dan potensi-potensi hasil penelitian Fakultas Biologi UGM termasuk melon dan olahannya. Berdasarkan hasil penelitian Sidiq dkk (2013) dan Hadi (2013) dari uji multilokasi, kultivar MG-3 memiliki karakter yang stabil untuk dibudidayakan pada musim hujan maupun musim kemarau. Melon kultivar MG-3 juga menunjukkan respon toleran terhadap virus Kyuri green mottle mosaic virus (Fitriyah, 2013).
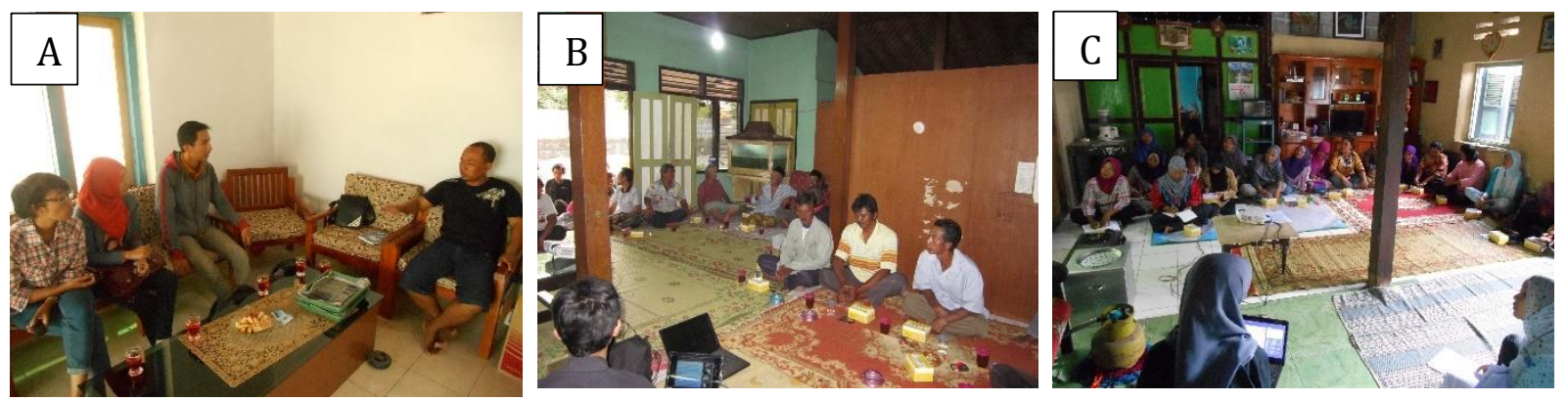

Gambar 1. Sosialisasi dan penyuluhan program, (A) Sosialisasi informal; (B) Penyuluhan kepada Kelompok Tani; (C) Penyuluhan kepada Kelompok PKK.

Pengembangan metode budidaya melon ramah lingkungan yang meliputi teknik pembenihan, teknik seleksi buah, dan teknik penggunaan potensi lokal (Daryono dkk, 2014) pada kegiatan ini adalah teknik diversifikasi olahan melon pasca panen yang bekerjasama dengan kelompok PKK untuk meningkatkan nilai ekonomi melon yang tidak terserap pasar, sehingga juga dilakukan sosialisasi da penyuluhan kepada kelompok PKK pedukuhan Jamusan (Gambar 1C).

2. Pelatihan (LANTPYCATION)

Pelatihan dilaksanakan sesuai dengan tahapan budidaya melon. Tahapan persiapan untuk media tanam dilakukan dengan pemanfaatan terhadap sisa abu vulkanik hasil erupsi gunung Kelud. Berdasarkan penelitian Rachmawati dan Daryono (2014), abu vulkanik memiliki potensi untuk digunakan dalam campuran media tanam pengganti pupuk komersial. Selanjutnya teknik pembenihan dilakukan dengan simulasi perakitan kultivar unggul untuk peningkatan kesadaran akan kualitas benih lokal unggul. Benih lokal unggul melon kultivar MG-3 memiliki ketahanan terhadap penyakit sehingga pestisida yang digunakan dapat dikurangi (Roziqin, 2013; Sidiq, 2014). Kemudian dilakukan penanaman benih melon bekerjasama dengan Bapak Romli selaku petani model sebagai mitra riset Fakultas Biologi UGM (Gambar 1A).

Pelatihan seleksi buah dilaksanakan ketika tanaman memasuki fase generatif, yaitu pada saat tanaman melon sudah berbuah lebih dari satu. Menurut Taiz dan Zeiger (2002), laju pertumbuhan tanaman akan memasuki fase penurunan ketika tanaman memasuki fase generatif. Pada saat fase generatif 
alokasi fotosintat oleh tumbuhan akan difokuskan pada organ reproduktif, khususnya buah (Myrna, 2013) sehingga perlu diberikan pelatihan teknik seleksi buah yang berpotensi menjadi buah yang baik dirawat, sementara buah yang lainnya dipetik (Gambar 1C), sedangkan pelatihan yang ditujukan kepada kelompok PKK dilakukan dengan tata cara pengolahan melon menjadi panganan tradisional semi-modern (Gambar 2B).

Menurut Camelo (2004), tipe pematangan buah terbagi atas buah klimaterik dan buah nonklimaterik, buah klimaterik merupakan buah yang mampu menghasilkan hormon etilen sehingga buah menjadi lunak meskipun buah sudah dipetik, sementara buah nonklimaterik merupakan buah yang tidak mengalami banyak perubahan setelah dipanen. Melon termasuk buah klimaterik sehingga mudah membusuk setelah panen dan MG-3 merupakan kultivar yang mampu bertahan dari 16 hari hingga 20 hari setelah panen (Sidiq dkk, 2013). Meskipun MG-3 termasuk kultivar melon dengan daya simpan yang lama, namun apabila buah tidak terserap pasar tetap akan memunculkan masalah baru, yaitu nilai jual buah melon menurun, buah terbuang percuma, dan bahkan buah menjadi limbah di sekitar lahan pertanian.Dalam pelatihan ini, melon yang tidak terserap pasar dan memiliki nilai jual yang rendah, diolah menjadi produk yang bernilai jual lebih tinggi sehingga dapat menambah pendapatan masyarakat Pedukuhan Jamusan.
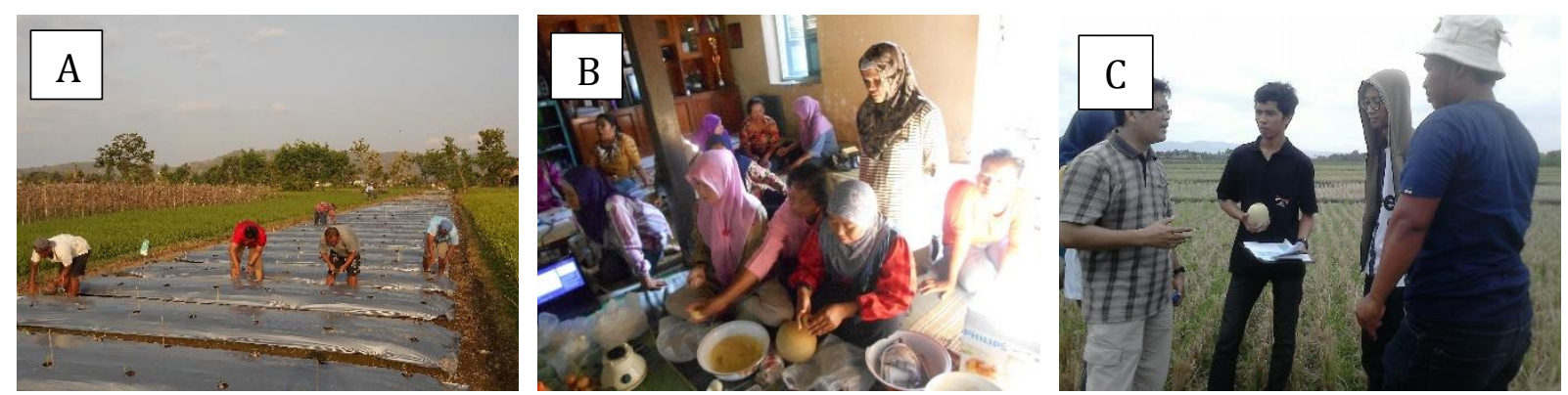

Gambar 2. Pelaksanaan pelatihan dalam aplikasi hasil penelitian, (A) Pelatihan penanaman dan teknik budidaya; (B) Pelatihan olahan melon; (C) Teknik seleksi buah.

Selama pelaksanaan pelatihan kegiatan pengolahan melon, sejauh ini telah diperoleh panganan olahan melon dengan berbagai macam varian jenis dan rasa. Gambar 3 merupakan beberapa produk olahan melon yang dihasilkan oleh kelompok PKK. Hingga saat ini produk yang dihasilkan dari pengolahan melon terdapat 8 jenis produk olahan yang terus dilakukan inovasi dan pengembangan untuk meningkatkan varian produk panganan olahan melon yang lebih baik. Produk tersebut terdiri dari kue, ice cream dan puding melon. Untuk kue sendiri terdiri dari Raghout Melon, Pizza Melon, Pie Melon, Donat Melon, Cup Cake Melon, Suri Melon, Kueku Melon. Hal ini membuktikan bahwa buah melon selain memiliki potensi untuk dijual dan dikonsumsi langsung juga 
memiliki potensi besar untuk dilakukan diversifikasi olahan dalam peningkatan nilai ekonomi dari buah melon yang tidak lolos standarisasi pasar.

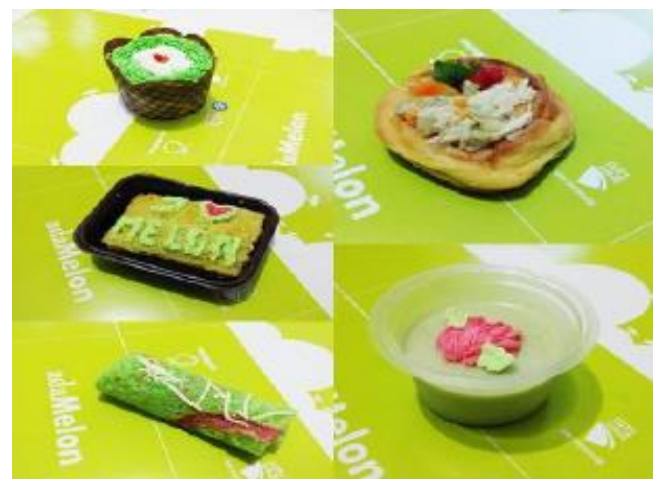

Gambar 3. Produk olahan melon

\section{Pendampingan berkala}

Pendampingan yang dilakukan yakni pembekalan informasi, monitoring, dan diskusi kepada perwakilan kelompok tani atau petani model. Hal ini dikmaksudkan agar terjadinya transfer ilmu antar petani demi terwujudnya kemandirian setelah kegiatan ini berakhir. Selain itu, pendampingan juga dilakukan dalam pembentukan struktur organisasi tim Petani Melon terpadu, yaitu Tim Sanggar Tani, dan Kelompok PKK Desa Jamusan khusus dalam pembuatan panganan olahan melon yaitu Tim Mamibalon (Makanan-Minuman Serba Melon).

Potensi hasil yang dapat dikembangkan untuk keberlanjutkan program agar mampu mensejahterakan masyarakat Desa Jamusan dapat dilihat dari potensi pertanian, ekonomi dan wisatanya.
Potensi pertanian yang dapat diserap dari adanya program aplikasi penelitian ini yaitu meningkatkan produksi melon untuk wilayah Yogyakarta dan sekitarnya yang diimbangi dengan kegiatan pemberdayaan hasil panen melon yang bernilai jual rendah oleh Kelompok PKK yang tergabung sebagai Tim Mamibalon.Potensi ekonomi yaitu terbukanya banyak lapangan pekerjaan bagi masyarakat Desa Jamusan khususnya anggota PKK dalam pengolahan panganan melon, sehingga dapat memunculkan makanan tradisional semi-modern khas Desa Jamusan dengan keunikan berupa bahan dasar serba melon yang padat karya dan bernilai ekonomi untuk peningkatan kesejahteraan masyarakat.Sedangkan Potensi wisata yang dapat diwujudkan yaitu Desa Jamusan menjadi desa sentra budidaya melon dengan buah tangan berupa makanan-minuman serba melon yang dapat dikembangkan menjadi Desa Wisata Melon Yogyakarta. Dan dapat menjadi role model bagi desa-desa lainnya dalam usaha memanfaatkan hasil panen melon yang memiliki nilai jual rendah.

4. Analisis ekonomi

Budidaya melon dengan teknik produksi benih dan seleksi buah dapat meningkatkan pendapatan petani dan mengurangi biaya produksi (Daryono dkk, 2014). Teknik produksi benih akan menjadikan petani mandiri benih dan dengan seleksi buah menjadikan hasil panen lebih optimum. 
Tabel 1. Analisis ekonomi sistem budidaya melon ramah lingkungan $\left(1000 \mathrm{~m}^{2} / 2000\right.$ tanaman) (Daryono dkk, 2014)

\begin{tabular}{|c|c|c|c|}
\hline No & Jenis Pengeluaran & Jumlah (Rp) & Penghasilan (Rp) \\
\hline 1 & Sewa lahan & 1.500 .000 & \\
\hline 2 & Benih melon 4 bungkus & 0 & \\
\hline 3 & $\begin{array}{l}\text { Pupuk kandang, Pupuk dasar } \\
\text { (Urea, TSP, KCl, ZA), Pupuk } \\
\text { kocor, Dolomit }\end{array}$ & 2.700 .000 & \\
\hline 4 & Mulsa & 500.000 & \\
\hline 5 & $\begin{array}{l}\text { Furadan, pestisida, fungisida, } \\
\text { dan obat-obatan }\end{array}$ & 850.000 & \\
\hline 6 & 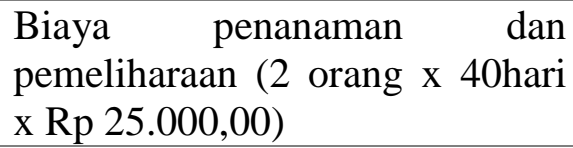 & 2.000 .000 & \\
\hline 7 & Biaya pemanenan & 100.000 & $\begin{array}{l}2000 \text { buah } \times 2 \mathrm{~kg} \times \\
\text { Rp } 5000\end{array}$ \\
\hline \multicolumn{2}{|c|}{ Total pengeluaran dan pendapatan } & 7.600 .000 & 20.000 .000 \\
\hline & Total laba & & 12.400.000/75 hari \\
\hline
\end{tabular}

Analisis ekonomi dengan minimal $1,5 \mathrm{~kg}$, net penuh, bentuk menggunakan sistem budidaya melon buah bulat dan tidak cacat. Pada ramah lingkungan memiliki nilai yang umumnya, akan terdapat $10 \%$ hasil lebih tinggi dibanding dengan sistem panen melon yang gagal dan tidak budidaya tradisional, dengan terserap pasar, sehingga apabila pengembangan metode sistem dilakukan analisis ekonomi akan budidaya melon ramah lingkungan diperoleh peningkatan nilai jual (LANTPYCATION) akan mencakup melon yang tidak terserap pasar resiko hasil panen yang tidak lolos tersebut (Tabel 2).

standarisasi pasar, yaitu berat buah

Tabel 2. Analisis ekonomi diversifikasi olahan melon

\begin{tabular}{clrr}
\hline No & \multicolumn{1}{c}{ Jenis Pengeluaran } & Jumlah (Rp) & Penghasilan (Rp) \\
\hline 1 & $\begin{array}{l}\text { Hasil panen yang tidak terserap } \\
\text { pasar 10\% (estimasi 200 buah) }\end{array}$ & 0 & $(-1.000 .000)$ \\
\hline 2 & Resep olahan melon & 200.000 & \\
\hline 3 & $\begin{array}{l}\text { Hasil produk olahan 5 @ 30buah } \\
\text { x Rp 5000 (harga jual minimal) }\end{array}$ & 0 & 750.000 \\
\hline Total pengeluaran dan pendapatan & 200.000 & 550.000 \\
\hline
\end{tabular}

Hasil panen yang tidak terserap pasar menyebabkan berkurangnya pendapatan petani, dan dengan dilakukan sistem pengolahan terhadap buah yang tidak terserap pasar (LANTPYCATION) dengan perhitungan minimal akan dapat menutupi setengah dari kerugian yang ditimbulkan. Pengembangan dari metode budidaya melon ramah lingkungan ini dengan melakukan pengolahan pada buah melon yang berpotensi menjadi limbah mencakupi 
resiko dari persentase panen melon

\section{SIMPULAN DAN SARAN}

1. Simpulan

\section{LANTPYCATION}

(Plant,

Apply, and Diversification) merupakan solusi dari permasalahan buah melon mulai dari pertanian, budidaya dan pengolahan melon yang menyatu menjadi sebuah program pemberdayaan atas dasar hasil penelitian ilmiah. Program ini bersifat twist empowerment yang komprehensif dan terpadu dan pengembangan dari metode budidaya melon ramah lingkungan. Metode yang diterapkan mampu meningkatkan pengetahuan masyarakat Desa Jamusan dengan konsep padat karya mengenai kualitas melon yang baik, tata cara manajemen pertanian dan budidaya melon yang tepat, serta menciptakan diversifikasi olahan melon untuk meningkatkan nilai jual melon bagi kesejahteraan masyarakat petani melon.

2. Saran

Program pengabdian masyarakat haruslah bersifat sustainability sehingga dibutuhkan dukungan dana yang berkelanjutan hingga program pengabdian tersebut dapat mandiri dan stabil di masyarakat. Masih banyak peluang implementasi hasil penelitian di perguruan tinggi yang dapat menggerakkan berbagai sektor dalam kehidupan masyarakat dalam mendukung sumber daya manusia Indonesia yang padat karya dalam menghadapi Masyarakat Ekonomi ASEAN (MEA) dan sebagai salah satu langkah konkret perguruan tinggi hadir ditengah-tengah masyarakat yang gagal.

memberikan fungsi pengaabdian masyarakat.

\section{DAFTAR PUSTAKA}

Badan Pusat Statistik Nasional. 2014. Data Luas Panen, Produksi, Produktivitas Melon. Sumber: http://www.pertanian.go.id/ap_ pages/mod/datahorti

Badan Pusat Statistik Sleman. 2014. Data Kecamatan Prambanan. Sumber: http://slemankab.bps.go.id/

Daryono, B.S., S.D. Hayuningtias, dan S.D. Maryanto. 2012. Perakitan Melon (Cucumis melo L.) Kultivar Melodi Gama 3 Dalam Rangka Penguatan Industri Pertanian Nasional. Prosiding Seminar Nasional dan Call for Paper EP UNNES.

Daryono, B.S., T. Joko, dan Purnomo. 2014. Budidaya Melon Ramah Lingkungan di Area Sekitar Gumuk Pasir. Jurnal Bioedukasi. 7 (1). Pp: 56-59

Data Monografi Desa Bokoharjo. 2013. Laporan Tahunan Kelurahan Bokoharjo. Arsip Kelurahan.

Direktorat Jenderal Holtikultura. 2004. Volume Impor Ekspor Benih Buah Tahun 2009-2012. Sumber:

http://hortikultura.deptan.go.id/i ndex.php?option=com_content $\&$ view $=$ article $\& i d=376 \&$ Itemid $=713$.

Doyle, M.P., L.R. Beuchat, and T.J. Montville. 2001. Food 
Microbiology Fundamentals and Frontiers $2^{\text {nd }}$. Washington DC: American Society For Microbiology.p.31

Fitriyah, F. 2013. Pewarisan Ketahanan Melon (Cucumis melo L.) Kultivar Melodi Gama 3 terhadap Kyuri green mottle mosaic virus. Skripsi. Fakultas Biologi Universitas Gadjah Mada. Yogyakarta.

Hadi, R. 2013. Phenotypic Characters Stability of Melodi Gama-3 Melon (Cucumis melo L.) Cultivar in Rainy Season Based on Multilocation Test. Prosiding. International Seminar on Applied Technology, Science, and Art (4 $4^{\text {th }}$ APTECS 2013)

Ivanova, P. H. 2012. The melonsRaw material forfood processing. In 50 years Food RDI InternationalScientificPractical Conference "Food, Technologiesand Health" Proceeding Book (pp. 023026). Plovdiv,Bulgaria.

Camelo L. andAndres F. 2004. Manual for the preparation and sale of fruits and vegetables : from field to market. FAO agricultural services bulletin, 1010-1365; 151

Munshi, A.D., and J.M. Alvarez. 2005. Hybrid Melon Development. Journal of New Seeds, 6 (4). Pp: 321-360

Myrna, N. 2013. Pertumbuhan Tanaman Jagung yang Diberi
Pupuk N Dengan Dosis dan Cara Pemberian yang Berbeda Pada Lahan Ultisols Dengan Sistem Olah Tanah Minimum. Jurnal Agronomi 10(1): 9-25

Rachmawati, Y. 2014. Karakter Fenotipdan Molekuler Melon (Cucumis melo L. "TACAPA") pada Media Tanam Tanah Karst. Thesis. Fakultas Biologi Universitas Gadjah Mada. Yogyakarta.

Roziqin. 2013. Ketahanan Tanaman Melon (Cucumis melo L.) Kultivar Melodi Gama 3 terhadap Jamur Tepung. Laporan Seminar. Fakultas Biologi Universitas Gadjah Mada. Yogyakarta

Samadi, B. 2007. Melon : Usaha Tani dan Penanganan Pasca Panen. Yogyakarta: Penerbit Kanisius. Hal.17.

Sidiq, Y. 2014. Identifikasi dan Pengembangan Penanda Molekular Sequence Characterized Amplified Region Terpaut Gen Ketahanan Terhadap Begomovirus pada Melon (Cucumis melo L.). Thesis. Fakultas Biologi Universitas Gadjah Mada. Yogyakarta.

Sidiq, Y., S. Maryanto, B.S. Daryono. 2013. Uji Adaptasi Multimusim Karakter Fenotip Kultivar Melodi Gama 3 (Cucumis melo L.): Usaha Penguatan Industri Benih Nasional. Prosiding Seminar Nasional X, Biologi, Sains, dan Pembelajarannya. Vol.10( 2). p.1 
34 Jurnal Pendidikan Matematika dan IPA Vol. 7. No. 1. Januari 2016: 25-34

Sobir dan Firmansyah, S. 2010. Taiz, L., and E. Zeiger. 2002. Plant Budidaya Melon Unggul. Physiology. 3rd ed. Sinauer Jakarta: Swadaya. Asscociation Publisher. Sunderland. P: $366-368$ 